\title{
Estimation of Annual Effective Dose Due to Ingestion of Natural Radionuclides in Cattle in Tin Mining Areas of Jos Plateau, Nigeria: Are Large Mammals Really Affected?
}

\author{
A. S. Aliyu1,2, T. A. Mousseau ${ }^{3}$, N. N. Garba',4, H. T. Abba2,5, A. T. Ramli ${ }^{2}$ \\ ${ }^{1}$ Department of Physics, Nasarawa State University Keffi, Nigeria \\ ${ }^{2}$ Department of Physics, Universiti Teknologi Malaysia, Johor, Malaysia \\ ${ }^{3}$ Department of Biological Sciences University of South Carolina, Columbia, SC, USA \\ ${ }^{4}$ Department of Physics, Ahmadu University Zaria, Nigeria \\ ${ }^{5}$ Department of Physics, Yobe State University Damaturu, Damaturu, Nigeria \\ Email: saabubakar2@live.utm.my, sadiqulkafawi4real@yahoo.co.uk
}

Received 7 March 2015; accepted 14 April 2015; published 15 April 2015

Copyright (C) 2015 by authors and Scientific Research Publishing Inc.

This work is licensed under the Creative Commons Attribution International License (CC BY). http://creativecommons.org/licenses/by/4.0/

c) (i) Open Access

\begin{abstract}
We have read with great interest the paper which was published in Natural Science, 2014 issue number 6 titled "Estimation of annual effective dose due to ingestion of natural radionuclides in cattle in tin mining area of Jos Plateau, Nigeria" [1]. The paper motivated us to use state-of-the-art computational technique to investigate the risks of the tin mining activity in Jos-Plateau, Nigeria on large mammals (e.g. cattle). The Tier 2 Erica Tool assessment was used to estimate the total dose rate and risk quotients of these reference terrestrial animals. Our investigation revealed that the expected and conservative risk quotients of large mammals due to internal and external exposure to enhanced level of radioactivity are 0.05 and 0.16 , respectively. Since the risk quotients are less than unity, this indicates that there is less than $5 \%$ probability that the screen dose rate $\left(10 \mu \mathrm{Gy} \cdot \mathrm{h}^{-1}\right)$ is exceeded. The estimated total dose rate to large mammals is $0.52 \mu \mathrm{Gy} \cdot \mathrm{h}^{-1}$ which is not statistically significant. A critical analysis of [1] is presented in the introductory part of this paper.
\end{abstract}

\section{Keywords}

Tin Mining, Radioecology, Biota, Jos, Dose Rate 


\section{Introduction}

The tin mining activities in the suburbs of Jos, Plateau State, Nigeria have resulted in technical enhancement of the background natural radiation as well as higher activity concentrations of primordial radionuclides in the topsoil of mining sites and their environs. In Jos, Nigeria, attempts have been made towards assessing the radiological consequence of mining in several localities [2]-[13]. A summary of the type of samples and results of each of these studies is presented in Table 1. Most of the studies on radiological effects of tin mining in Jos, Nigeria have only considered the human health risks.

A recent study by Ademola [1] attempted to measure the activity concentrations of ${ }^{226} \mathrm{Ra},{ }^{232} \mathrm{Th}$, and ${ }^{40} \mathrm{~K}$ in cattle that were believed to have grazed in the fields around the mining region. The study calculated the effective dose based on the consumption of meat from the cattle in this region. The study reported high activity concentration of ${ }^{40} \mathrm{~K}$ in the studied cattle organs. However, there are some deficiencies of the study design and presentation that raise questions concerning the validity of the findings. Although the paper is very well written and deserves to be recognized as a remarkable contribution to the field of natural radiation studies in Nigeria, it has some shortcomings. These shortcomings are highlighted and discussed below.

We have been following studies from this region with technically enhanced background radiation level due to tin mining activities in the suburbs of Jos Plateau State, Nigeria [2] [5]-[9] [13]. The findings of some of these studies have been presented in one of our most recent papers [15] and Table 1.

Ademola [1] should have designed a good epidemiological study and the discussions of the results should have been strengthened with robust statistics. The author presented the activity concentrations of primordial radionuclides in the organs of cattle without justifying the results. The study considered just five cattle that were slaughtered in a local abattoir believing the animals had grazed in fields and farmlands that have technically enhanced levels of radioactivity due to mining activities in the region. This is misleading because of the nomadic life style of herdsmen in Nigeria and West Africa. Herdsmen regularly move their cattle to different parts of Nigeria, and in some cases even West Africa, depending on the season's climatic conditions in order to find green fields for their animals [16]. This factor could have resulted in confounding issues that would have biased the results of the study. In a recent study, we have discussed confounding issues in radioecology of the world's high background natural radiation areas [17].

Table 1. Summary of activity concentrations in soil and dose due to tin mining in Jos Nigeria [14].

\begin{tabular}{|c|c|c|c|c|c|c|c|}
\hline \multirow[b]{2}{*}{ Study } & \multicolumn{4}{|c|}{ Activity concentrations of radionuclides $\left(\mathrm{Bq} \cdot \mathrm{kg}^{-1}\right)$} & \multirow[b]{2}{*}{$\begin{array}{c}\text { In situ dose } \\
\text { measurements } \\
\left(\mu \mathrm{Sv} \cdot \mathbf{h}^{-1}\right)\end{array}$} & \multirow[b]{2}{*}{ Mine Location } & \multirow[b]{2}{*}{ Type of sample } \\
\hline & ${ }^{238} \mathbf{U}$ & ${ }^{226} \mathbf{R a}$ & ${ }^{232} \mathrm{Th}$ & ${ }^{40} \mathbf{K}$ & & & \\
\hline Ibeanu [5] & 3779.1 & NA & 8175.2 & NA & NA & Jos tin Mine & Contaminated soil \\
\hline Ademola [12] & 722 & NA & 1680 & Not detected & NA & Jos tin Mine & Tin tailing \\
\hline Ademola, Farai [13] & NA & 66 & 126 & 589 & NA & $\begin{array}{l}\text { Tin mining areas of } \\
\text { Bukuru and Bitsichi, Jos }\end{array}$ & $\begin{array}{l}\text { Concrete building } \\
\text { blocks }\end{array}$ \\
\hline Ajayi [2] & 776.0 & NA & 2.72 & 35.4 & NA & Soil samples & $\begin{array}{l}\text { Tin mine in } \\
\text { Baukuru-Jos }\end{array}$ \\
\hline Arogunjo et al. [3] & $(8.7-51)$ & NA & $(16.8-98)$ & NA & NA & $\begin{array}{l}\text { Tin mining area of } \\
\text { Bitsichi, Jos }\end{array}$ & $\begin{array}{l}\text { Soil and } \\
\text { mineral sands }\end{array}$ \\
\hline Funtua, Elegba [4] & NA & NA & NA & NA & $(5-80)$ & Tin mines, Bukuru & NA \\
\hline Jibiri et al. [6] & NA & $(109-163)$ & $(147-451)$ & $(466-1062)$ & NA & $\begin{array}{l}\text { Bitsichi, Bukuru and } \\
\text { Ropp localities, Jos }\end{array}$ & $\begin{array}{l}\text { Farm soil from the } \\
\text { three localities }\end{array}$ \\
\hline Jibiri et al. [7] & (BDL-48) & NA & (BDL-17) & $(60-494)$ & NA & Old tin mine of Bitsichi & $\begin{array}{l}\text { Food items, soil } \\
\text { and local diets }\end{array}$ \\
\hline Jibiri, Agomuo [8] & NA & $(19-30)$ & $(27-41)$ & $(83-129)$ & NA & Old tin mine of Bitsichi & $\begin{array}{l}\text { Terrestrial food } \\
\text { crops }\end{array}$ \\
\hline Jibiri et al. [9] & NA & $(109-470.6)$ & $(122.7$ - 2189.5) & BDL-166.4 & NA & Old tin mine of Bitsichi & Soil \\
\hline Olise et al. [10] & $(1.0 \pm 40)$ & NA & $(6.0-170)$ & NA & NA & $\begin{array}{c}\text { Bukuru, Bitsichi and } \\
\text { Kuru }\end{array}$ & Soil and tailing \\
\hline Olise et al. [11] & BDL-27420 & NA & $(50-35,800)$ & $(30-670)$ & NA & $\begin{array}{l}\text { Bitsichi, Kuru } \\
\text { and Bukuru }\end{array}$ & Tailing \\
\hline
\end{tabular}


Another issue is the very small sample size and the inability of the author to include proper controls. The author should have also considered cattle that were from non-mining areas of Jos. This would have helped the author in justifying the assumption that the dumping of mine tailings and the dispersion of excavated soil with enhanced radioactivity to some locations around the mining field would have influenced the activity concentrations in cattle from mining areas.

Another crucial factor that was overlooked by Ademola [1] was the age of the animals. This would provide insight as to whether the older animals had accumulated more radionuclides than the younger ones. This is hypothetically justifiable as older animals should have grazed on these "contaminated" fields the most. The author's failure to compare her results with earlier studies that were conducted in the study area is also a major limitation. For instance, [8], [7] and [9] have presented data on the activity concentrations of natural radionuclides in food samples from the same area.

Ademola [1] could have been enhanced if the author had considered if there was a relationship between radionuclide concentrations in the blood and any of the organs of interest. This is because ${ }^{226} \mathrm{Ra}$ is soluble in water and highly mobilizable [10] [18] [19]. This study could have also considered the radioecology of the studied animals which is also known to have important consequences for radionuclide uptake and deposition. For example, a simple run of the ERICA Tool [20]-[22], a state-of-the-art-software for assessing the impacts of exposure to ionizing radiation on non-human biota should have addressed this. Some of the contributing authors of this Letter have used ERICA for preliminary impact assessments of the Fukushima nuclear accident on non-human biota [23] [24] and for environmental impact assessments of the new nuclear power plant in Nigeria [25]-[27].

It is our opinion that given the small sample size, the lack of controls, and an incomplete radioecological analysis, the suggestion that mine tailings are the underlying cause of higher activity concentration of ${ }^{40} \mathrm{~K}$ cannot be justified. In Nigeria, cattle graze on harvested fields and on byproducts of farming that are not needed by the peasant farmers for food. The application of inorganic fertilizer which is made of elements like NPK (Nitrogen, phosphorus, potassium) will influence the activity concentration of ${ }^{40} \mathrm{~K}$ in the cattle feeds and hence their organs. The radioactivity of NPK fertilizer is well documented in the literature [28]-[30] and this is likely the cause of the reported findings. We understand that some of the highlighted deficiencies could be attributed to lack of funding but we hope the author will take some of our comments into consideration in any future study.

Several studies have considered the radiological human health risks of the mining activity; however, to our knowledge no documented study has investigated the radiological impacts on biota. Hence, an attempt is made to cover this information gap using published data from the literature and the ERICA Tool. Such a study is both timely and relevant given the growing international interest in the biological impacts of low dose radiation in the environment.

\section{Material and Methods}

Published data on the activity concentration of 238U, and 232Th in soil and tailings from Bukuru, Kuru and Bitsichi were used to conduct a Tier 2 ERICA Tool impact assessment to estimate the dose rate and risk quotients for the reference terrestrial species. The universal screening dose rate criterion of $10 \mu \mathrm{Gy} \cdot \mathrm{h}^{-1}$ was used for the assessment procedure. Such a level is often assumed to result in negligible environmental risks [31]. This methodology has proven useful for the assessment of impacts to biota due to exposure to Fukushima-derived radionuclides in marine, freshwater and terrestrial ecosystems [32] [33]. In order to follow regulatory standards, the upper bound of the reported range value for $238 \mathrm{U}$ and 232Th that have been reported by Ibeanu [5] were used as these two studies considered all mining areas (Table 1).

\section{Brief Description of ERICA Tool}

There are three elements of the ERICA integrated approach, which are to aid decision-making related to the environmental effects of ionizing radiation; the elements have been combined into the ERICA Integrated Approach. These are assessment of environmental exposure and effects using the ERICA Tool, risk characterization, and management of environmental risks [29] [34].

Tier 1: is designed to be simple and conservative, requiring a minimum of input data and enabling the user to exit the process and exempt the situation from further evaluation, provided the assessment meets a predefined screening criterion. Here the predefined screening dose is used to calculate the environmental media concentration limit (EMCL) for all reference organism/radionuclide combinations. 
In Tier 1, the risk quotient (RQ) is then obtained by comparing the input media concentrations with the most restrictive EMCL for each radionuclide. These are defined by Equation (1).

$$
\mathrm{RQ}_{n}=\frac{\mathrm{AC}_{n}}{\mathrm{EMCL}_{n}}
$$

where, AC is the measured activity concentration in the medium for a specific radionuclide $n$.

If $\mathrm{RQ}<1$, then the probability of exceeding the benchmark is acceptably low $(<5 \%)$ and this serves as the justification for terminating risk calculations at this stage. In a situation where RQ $>1$, there is $>5 \%$ probability that the benchmark has been exceeded and further assessment is recommended (Tier 2).

The basic equations for Tier 2 assessment are presented in Equations (2) and (3).

$$
\dot{D}_{\mathrm{int}}^{j}=\sum_{i} C_{i}^{j} \cdot \mathrm{DCC}_{\mathrm{int}, i}^{j}
$$

where $C_{i}^{j}$ is the average concentration radionuclide $i$ in the reference organism $j\left(\mathrm{~Bq} \cdot \mathrm{Kg}^{-1}\right.$ fresh weight); DCC $_{\text {int, }, i}^{j}$ is the radionuclide specific dose conversion coefficient for internal exposure $\left(\mu \mathrm{G} \cdot \mathrm{h}^{-1}\right.$ per $\mathrm{Bq} \cdot \mathrm{Kg}^{-1}$ fresh weight).

$$
\dot{D}_{\mathrm{ext}}^{j}=\sum_{z} v_{z} \sum_{i} C_{z i}^{\mathrm{ref}} \cdot \mathrm{DCC}_{\mathrm{ext}, z i}^{j}
$$

where $v$ is the occupancy factor of the organism $j$ at location $z ; C_{z i}^{\text {ref }}$ is the average concentration of radionuclide $i$ in the reference media in a given location $z$, and DCC $_{\text {ext, } z i}^{j}$ is dose conversion coefficient for external exposure. The total dose rate $\dot{D}_{\text {Tot }}^{j}$ is assessed by summing the two Equations (1) and (2). Two RQ (Expected $\left[\mathrm{RQ}_{\exp }\right]$ and Conservative $\left[\mathrm{RQ}_{\text {cons }}\right]$ ) are obtained at the end of this assessment.

Tier 2: This allows the modeler to be more interactive, to change the default parameters (screening dose rate and radionuclides) and to select specific reference organisms. The evaluation is performed directly against the screening dose rate, with the dose rate and $\mathrm{RQ}_{s}$ generated for each reference organism selected for assessment. A "traffic light" system is used to indicate whether the situation can be considered:

1) Green: of negligible concern (with a high degree of confidence);

2) Yellow: of potential concern, where more qualified judgments may need to be made and/or a refined assessment at Tier 2 or an in-depth assessment in Tier 3 performed; and

3) Red: of concern, where the user is recommended to continue the assessment, either at Tier 2 if refined input data can be obtained, or at Tier 3 .

Decisions to exit an assessment given outcomes 2) and 3) should be justified, for example by using information from FREDERICA provided in the Tool as "look-up effects tables” for different wildlife groups.

In Tier 2, the total risk quotient is calculated as

$$
\sum \mathrm{RQ}=\frac{D_{\text {Tot }}}{D_{\text {lim }}}
$$

where $D_{\text {Tot }}$ is the total dose rate and $D_{\lim }$ is the screening dose rate.

Tier 3 is a probabilistic risk assessment in which uncertainties within the results may be determined using sensitivity analysis. The assessor can also access up-to-date scientific literature (which may not be available at Tier 2) on the biological effects of exposure to ionizing radiation in a number of different species.

Detailed descriptions of the ERICA tool and the integrated approach for ecological impact assessment have previously been presented in the literature [20] [21] [32] [34]-[36].

\section{Results and Conclusions}

The results of the Tier 2 ERICA Tool run based on the data reported by Ibeanu [5] are presented in Figure 1. The models show very large variation among different groups in the predicted dose rates. The graph (Figure 1) indicates two threshold dose rate levels of interest. The first is the $10 \mu \mathrm{Gy} \cdot \mathrm{h}^{-1}$ level that is considered of interest by those promoting the ERICA tool (e.g. Beresford, etc.); the ERICA universal dose rate is assumed for all ecosys- 


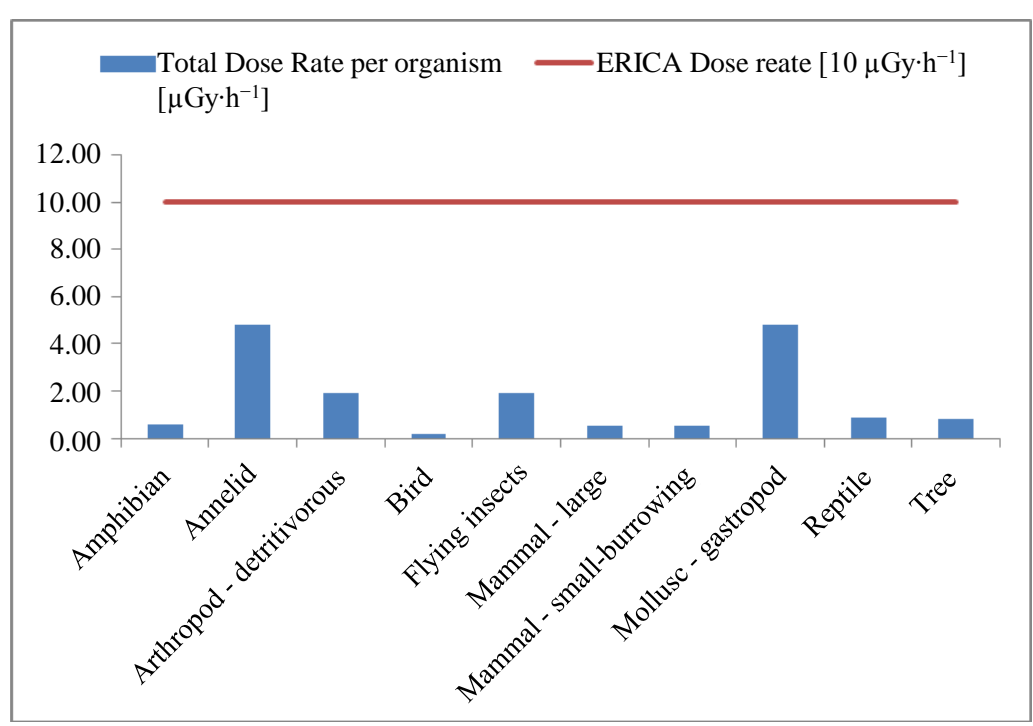

Figure 1. Total dose rate to reference terrestrial organisms due to tin mining.

tems. The second is $40 \mu \mathrm{Gy} \cdot \mathrm{h}^{-1}$ which is felt by IAEA [37], UNSCEAR [38], and USDoE [39] to be of significance for terrestrial animals. It has been previously suggested that below this value of chronic exposure to radiation, measurable population effects will occur. It is worth noting that there is ongoing discussion on this threshold value, given controversial studies of organisms living in the forests of Chernobyl [40] [41].

The expected and conservative risk quotients for large mammals due to internal and external exposure to enhanced level of radioactivity are 0.05 and 0.16 , respectively. Since all risk quotients are less than unity, this indicates that there is less than $5 \%$ probability that the screen dose rate of $10 \mu \mathrm{Gy} \cdot \mathrm{h}^{-1}$ is exceeded. The organisms that receive the maximum total dose are mollusc-gastropod and annelid (earth worm). There is need to further investigate the impacts of chronic exposure to low-dose rate ionizing radiation using field data by directly observing any physiological or morphological aberrations in the specific organism and comparing the data with that of controls. The dose rate to our animal of interest, large mammal is relatively low $\left(0.52 \mu \mathrm{Gy} \cdot \mathrm{h}^{-1}\right)$ and the risk quotients are less than unity indicating that large mammals (cattle) are not at risk.

This paper assessed the potential radioecological impacts of tin mining in Jos, Nigeria, with the aim of investigating if large mammals are affected by the enhanced levels of radioactivity in the soil, which is due to tin mining and milling. The results of this study have shown that terrestrial organisms like mollusc-gastropod and annelid (earth worm) receive the maximum estimated dose rate of $4.7 \mu \mathrm{Gy} \cdot \mathrm{h}^{-1}$. While the estimated dose rate for large mammal is far less than the universal screening dose rate of $10 \mu \mathrm{Gy} \cdot \mathrm{h}^{-1}$, which suggests that the animals are not likely at risk.

\section{Acknowledgements}

Dr. A.S. Aliyu would like to acknowledge the support of the Research Management Center of Universiti Teknologi Malaysia for its support through the Post-Doc fellowship scheme under the grant (Q.J130000.21A2.01E98).

\section{References}

[1] Ademola, J.A. (2014) Estimation of Annual Effective Dose Due to Ingestion of Natural Radionuclides in Cattle in Tin Mining Area of Jos Plateau, Nigeria. Natural Science, 6, 255-261. http://dx.doi.org/10.4236/ns.2014.65029

[2] Ajayi, I.R. (2008) An Evaluation of the Equivalent Dose Due to Natural Radioactivity in the Soil around the Consolidated Tin Mine in Baukuru-Jos, Plateau State of Nigeria. Iranian Journal of Radiation Research, 5, 203-206.

[3] Arogunjo, A.M., Höllriegl, V., Giussani, A., Leopold, K., Gerstmann, U., Veronese, I. and Oeh, U. (2009) Uranium and Thorium in Soils, Mineral Sands, Water and Food Samples in a Tin Mining Area in Nigeria with Elevated Activity. Journal of Environmental Radioactivity, 100, 232-240. http://dx.doi.org/10.1016/j.jenvrad.2008.12.004

[4] Funtua, I.I. and Elegba, S.B. (2005) Radiation Exposure from High-Level Radiation Area and Related Mining and Processing Activities of Jos Plateau, Central Nigeria. International Congress Series, 1276, 401-402. 
http://dx.doi.org/10.1016/j.ics.2004.10.006

[5] Ibeanu, I.G.E. (2002) Tin Mining and Processing in Nigeria: Cause for Concern? Journal of Environmental Radioactivity, 64, 59-66. http://dx.doi.org/10.1016/S0265-931X(02)00058-9

[6] Jibiri, N.N., Alausa, S.K. and Farai, I.P. (2009) Assessment of External and Internal Doses Due to Farming in High Background Radiation Areas in Old Tin Mining Localities in Jos-Plateau, Nigeria. Radioprotection, 44, 139-141. http://dx.doi.org/10.1051/radiopro/2009001

[7] Jibiri, N.N., Farai, I.P. and Alausa, S.K. (2007) Estimation of Annual Effective Dose Due to Natural Radioactive Elements in Ingestion of Foodstuffs in Tin Mining Area of Jos-Plateau, Nigeria. Journal of Environmental Radioactivity, 94, 31-40. http://dx.doi.org/10.1016/j.jenvrad.2006.12.011

[8] Jibiri, N.N. and Agomuo, J.C. (2007) Trace Elements and Radioactivity Measurements in Some Terrestrial Food Crops in Jos-Plateau, North Central, Nigeria. Radioprotection, 42, 29-42. http://dx.doi.org/10.1051/radiopro:2006026

[9] Jibiri, N.N., Farai, I.P. and Alausa, S.K. (2007) Activity Concentrations of ${ }^{226}$ Ra, ${ }^{228}$ Th, and ${ }^{40}$ K in Different Food Crops from a High Background Radiation Area in Bitsichi, Jos Plateau, Nigeria. Radiation and Environmental Biophysics, 46, 53-59. http://dx.doi.org/10.1007/s00411-006-0085-9

[10] Olise, F.S., Oladejo, O.F., Almeida, S.M., Owoade, O.K., Olaniyi, H.B. and Freitas, M.C. (2014) Instrumental Neutron Activation Analyses of Uranium and Thorium in Samples from Tin Mining and Processing Sites. Journal of Geochemical Exploration, 142, 36-42. http://dx.doi.org/10.1016/j.gexplo.2014.01.004

[11] Olise, F.S., Owoade, O.K., Olaniyi, H.B. and Obiajunwa, E.I. (2010) A Complimentary Tool in the Determination of Activity Concentrations of Naturally Occurring Radionuclides. Journal of Environmental Radioactivity, 101, 910-914. http://dx.doi.org/10.1016/j.jenvrad.2010.06.006

[12] Ademola, J.A. (2008) Exposure to High Background Radiation Level in the Tin Mining Area of Jos Plateau, Nigeria. Journal of Radiological Protection, 28, 93-99. http://dx.doi.org/10.1088/0952-4746/28/1/006

[13] Ademola, J.A. and Farai, I.P. (2006) Gamma Activity and Radiation Dose in Concrete Building Blocks Used for Construction of Dwellings in Jos, Nigeria. Radiation Protection Dosimetry, 121, 395-398. http://dx.doi.org/10.1093/rpd/ncl052

[14] Aliyu, A.S., Mousseau, T.A. and Ramli, A.T. (2015) Preliminary Investigation of the Radioecological Impacts of Tin Mining in Jos Nigeria: Is There an Issue of Environmental Concern? AMBIO, Forthcoming.

[15] Aliyu, A.S., Ibrahim, U., Akpa, C.T., Garba, N.N. and Ramli, A.T. (2015) Health and Ecological Hazards Due to Natural Radioactivity in Soil from Mining Areas of Nasarawa State, Nigeria. Isotopes in Environmental and Health Studies, in Press.

[16] Bassett, T.J. (1986) Fulani Herd Movements. Geographical Review, 76, 233-248. http://dx.doi.org/10.2307/214143

[17] Aliyu, A.S. and Ramli, A.T. (2015) The World's High Background Natural Radiation Areas (HBNRAs) Revisited: A Broad Overview of the Dosimetric, Epidemiological and Radiobiological Issues. Radiation Measurements, 73, 51-59. http://dx.doi.org/10.1016/j.radmeas.2015.01.007

[18] Mortazavi, S., Ghiassi-Nejad, M. and Beitollahi, M. (2001) Very High Background Radiation Areas (VHBRAs) of Ramsar: Do We Need Any Regulations to Protect the Inhabitants? Proceedings of the 34th Midyear Meeting Radiation Safety and ALARA-Considerations for the 21st Century, Anaheim, 4-7 February 2001, 177-182.

[19] Dissanayake, C.B. and Chandrajith, R. (2009) Introduction to Medical Geology. Springer, Dordrecht. http://dx.doi.org/10.1007/978-3-642-00485-8

[20] Beresford, N., Brown, J., Copplestone, D., Garnier-Laplace, J., Howard, B., Larsson, C.-M., Oughton, D., Prohl, G. and Zinger, I. (2007) D-ERICA: An Integrated Approach to the Assessment and Management of Environmental Risk from Ionising Radiation. Description of Purpose, Methodology and Application. EC Contract Number FI6R-CT-2004508847, European Commission, Brussels.

[21] Brown, J., Alfonso, B., Avila, R., Beresford, N.A., Copplestone, D., Pröhl, G. and Ulanovsky, A. (2008) The ERICA Tool. Journal of Environmental Radioactivity, 99, 1371-1383. http://dx.doi.org/10.1016/j.jenvrad.2008.01.008

[22] Brown, J.E. (2013) Introduction to the ERICA Tool. Norwegian Radiation Protection Authority.

[23] Aliyu, A.S., Ramli, A.T., Garba, N.N., Saleh, M.A., Gabdo, H.T. and Liman, M.S. (2015) Fukushima Nuclear Accident: Preliminary Assessment of the Risks to Non-human Biota. Radiation Protection Dosimetry, 163, $238-250$. http://dx.doi.org/10.1093/rpd/ncu158

[24] Aliyu, A.S., Wu, J., Mousseau, T.A. and Ramli, A.T. (2015) Current Knowledge Concerning the Impacts of the Fukushima Daiichi Nuclear Power Plant Accident on the Environment. Energy Environmental Science, Forthcoming.

[25] Aliyu, A., Ramli, A. and Saleh, M. (2014) Environmental Impact Assessment of a New Nuclear Power Plant (NPP) Based on Atmospheric Dispersion Modeling. Stochastic Environmental Research and Risk Assessment, 27, $1897-1911$. http://dx.doi.org/10.1007/s00477-014-0856-9 
[26] Aliyu, A.S. (2014) Atmospheric Dispersion Analysis for Potential Radiological Impact Assessment of Nigeria’s Pioneer Nuclear Power Plant. Ph.D. Dissertation, Universiti Teknologi Malaysia, Johor.

[27] Aliyu, A.S., Ramli, A.T. and Saleh, M.A. (2015) Assessment of Potential Human Health and Environmental Impacts of a Nuclear Power Plant (NPP) Based on Atmospheric Dispersion Modeling. Atmósfera, 28, 13-26. http://dx.doi.org/10.1016/S0187-6236(15)72156-9

[28] Fávaro, D. (2005) Natural Radioactivity in Phosphate Rock, Phosphogypsum and Phosphate Fertilizers in Brazil. Journal of Radioanalytical and Nuclear Chemistry, 264, 445-448. http://dx.doi.org/10.1007/s10967-005-0735-4

[29] Boukhenfouf, W. and Boucenna, A. (2011) The Radioactivity Measurements in Soils and Fertilizers Using Gamma Spectrometry Technique. Journal of environmental radioactivity, 102, 336-339. http://dx.doi.org/10.1016/j.jenvrad.2011.01.006

[30] Pfister, H., Philipp, G. and Pauly, H. (1976) Population Dose from Natural Radionuclides in Phosphate Fertilizers. Radiation and Environmental Biophysics, 13, 247-261. http://dx.doi.org/10.1007/BF01330769

[31] Larsson, C.-M. (2008) An Overview of the ERICA Integrated Approach to the Assessment and Management of Environmental Risks from Ionising Contaminants. Journal of Environmental Radioactivity, 99, 1364-1370. http://dx.doi.org/10.1016/j.jenvrad.2007.11.019

[32] Aliyu, A.S., Ramli, A.T., Garba, N.N., Saleh, M.A., Gabdo, H.T. and Liman, M.S. (2015) Fukushima Nuclear Accident: Preliminary Assessment of the Risks to Non-Human Biota. Radiation Protection Dosimetry, 163, 238-250. http://dx.doi.org/10.1093/rpd/ncu158

[33] Garnier-Laplace, J., Beaugelin-Seiller, K. and Hinton, T.G. (2011) Fukushima Wildlife Dose Reconstruction Signals Ecological Consequences. Environmental Science \& Technology, 45, 5077-5078. http://dx.doi.org/10.1021/es201637c

[34] Torrud, J. and Saetre, P. (2013) Assessment of Long-Term Radiological Effects on Plants and Animal from Deep Geological Respiratory: No Discernible Impact Detected. AMBIO, 42, 506-516. http://dx.doi.org/10.1007/s13280-013-0403-9

[35] Larsson, C.-M. (2008) An Overview of the ERICA Integrated Approach to the Assessment and Management of Environmental Risks from Ionising Contaminants. Journal of Environmental Radioactivity, 99, 1364-1370. http://dx.doi.org/10.1016/j.jenvrad.2007.11.019

[36] Torudd, J. (2010) Long Term Radiological Effects on Plants and Animals of a Deep Geological Repository: SR-Site Biosphere. Svensk Kärnbränslehantering AB, Swedish Nuclear Fuel and Waste Management Company, Stockholm.

[37] IAEA (1992) Effects of Ionising Radiation on Plants and Animals at Levels Implied by Current Radiation Protection Standards. Technical Reports Series No. 332, International Atomic Energy Agency, Vienna.

[38] UNSCEAR (1996) Sources and Effects of Ionizing Radiation. Report to the General Assembly with Scientific Annex A/AC.82/R.54, United Nations, Vienna.

[39] USDoE (2002) A Graded Approach for Evaluating Radiation Doses to Aquatic and Terrestrial Biota. Technical Standard DoE-STD-1153-2002, Washington DC.

[40] Garnier-Laplace, J., Geras’kin, S., Della-Vedova, C., Beaugelin-Seiller, K., Hinton, T.G., Real, A. and Oudalova, A. (2013) Are Radiosensitivity Data Derived from Natural Field Conditions Consistent with Data from Controlled Exposures? A Case Study of Chernobyl Wildlife Chronically Exposed to Low Dose Rates. Journal of Environmental Radioactivity, 121, 12-21. http://dx.doi.org/10.1016/j.jenvrad.2012.01.013

[41] Møller, A.P. and Mousseau, T.A. (2011) Efficiency of Bio-Indicators for Low-Level Radiation under Field Conditions. Ecological Indicators, 11, 424-430. http://dx.doi.org/10.1016/j.ecolind.2010.06.013 